\title{
ADVERSITY QUOTIENT DAN PENALARAN KREATIF MATEMATIS SISWA SMA DALAM PEMBELAJARAN ARGUMENT DRIVEN INQUIRY PADA MATERI TURUNAN FUNGSI
}

\author{
Wahyu Hidayat \\ STKIP Siliwangi Bandung \\ manual_emotional@yahoo.com
}

\begin{abstract}
ABSTRAK
Studi ini dirancang dalam bentuk eksperimen dengan disain kelompok kontrol dan postes saja yang bertujuan menelaah peranan pembelajaran Argument Driven Inquiry (ADI) terhadap kemampuan penalaran kreatif matematis siswa SMA berdasarkan Adversity Quotient (AQ). Populasi dalam penelitian ini adalah siswa SMA di Kota Cimahi, sedangkan sampel penelitian ini adalah 69 orang siswa SMA yang ditetapkan secara purposif kemudian ditetapkan secara acak yang termasuk ke dalam kelas eksperimen dan kelas kontrol. Berdasarkan hasil dan pembahasan diperoleh kesimpulan: (1) Kemampuan penalaran kreatif matematis siswa yang memperoleh pembelajaran Argument Driven Inquiry (ADI) lebih baik daripada yang memperoleh pembelajaran langsung ditinjau berdasarkan keseluruhan dan tipe Adversity Quotient (Quitter/AQ Rendah, Champer/AQ Sedang, dan Climber/AQ Tinggi) ; (2) Faktor pembelajaran dan tipe Adversity Quotient (AQ) masing-masing mempengaruhi ketercapaian kemampuan penalaran kreatif matematis siswa. Selain itu, terdapat efek interaksi antara pembelajaran dan AQ secara bersamasama dalam mengembangkan kemampuan penalaran kreatif matematis siswa; (3) Ketercapaian penguasaan kemampuan penalaran kreatif matematis siswa masih belum tercapai dengan baik pada indikator kebaruan (novelty).
\end{abstract}

Kata Kunci : Adversity Quotient, Argument Drivent Inquiry, Penalaran Kreatif Matematis

\section{PENDAHULUAN}

Tujuan pembelajaran matematika yakni: (1) melatih bagaimana memahami sesuatu melalui berpikir dan bernalar untuk menarik suatu kesimpulan, (2) mengembangkan kreativitas peserta didik dengan melibatkan intuisi, imajinasi, dan suatu penemuan yang dikembangkan dari pemikiran rasa ingin tahu, divergen, orisinil, sehingga dapat membuat prediksi atau dugaan untuk memecahkan suatu permasalahan yang dihadapi, (3) mengembangkan kemampuan memecahkan masalah, dan (4) mengembangkan kemampuan menyampaikan informasi dan mengkomunikasikan gagasan. Depdiknas (2006) menjelaskan bahwa tujuan dari pembelajaran matematika yaitu: (a) memahami konsep matematika, menjelaskan keterkaitan antar konsep dan mengaplikasikan konsep atau algoritma secara luwes, akurat, efisien, dan tepat dalam pemecahan masalah, (b) menggunakan penalaran pada pola dan sifat, melakukan manipulasi matematika dalam 
membuat generalisasi, menyusun bukti, atau menjelaskan gagasan dan pernyataan matematika, (c) memecahkan masalah yang meliputi kemampuan memahami masalah, merancang model matematika, menyelesaikan model, dan menafsirkan solusi yang diperoleh, d) mengkomunikasikan gagasan dengan simbol, tabel, diagram, atau media lain untuk memperjelas keadaan atau masalah, dan (e) memiliki sikap menghargai kegunaan matematika dalam kehidupan yaitu rasa ingin tahu, perhatian, dan minat dalam mempelajari matematika, serta sikap ulet dan percaya diri dalam pemecahan masalah. Sehingga selayaknya pengembangan pembelajaran matematika di Sekolah harus memperhatikan bahwa matematika merupakan salah satu sarana pembentukan pola pikir siswa yang dapat diukur dari kemampuan. Sehingga sudah jelaslah bahwa agar siswa (peserta didik) memiliki kemampuan matematika yang baik, maka guru matematika sebagai faktor pendukungnya juga harus memiliki kemampuan matematika yang baik pula.

Salah satu kemampuan yang dapat membentuk pola pikir seseorang yaitu kemampuan penalaran matematis. Hal tersebut sejalan yang kemukakan Killpatrick, Swafford \& Findell (2001) bahwa kemampuan yang diperlukan seseorang dalam memecahkan suatu permasalahan adalah komponen-komponen dalam kecakapan matematis, yakni: (1) pemahaman konsep (conceptual understanding); (2) kelancaran prosedural (procedural fluency); (3) kompetensi strategis (strategic competence); (4) penalaran adaptif (adaptive reasoning); dan (5) disposisi produktif (productive disposition).

Seni bernalar sangat dibutuhkan di setiap segi dan setiap sisi kehidupan ini agar setiap warga bangsa dapat menunjukan dan menganalisis setiap masalah yang muncul secara jernih; dapat memecahkan masalah dengan tepat; dapat menilai sesuatu secara kritis dan objektif; serta dapat mengemukakan pendapat maupun idenya secara runtut dan logis Shadiq (2007). Selanjutnya, Shadiq (2007) menyebutkan bahwa penalaran merupakan aktivitas berpikir untuk menarik kesimpulan atau membuat suatu pernyataan baru berdasarkan beberapa pernyataan yang diketahui benar atau dianggap benar yang disebut premis.

Bergqvist (2007) mengemukakan kerangka kerja penalaran matematika yang digambarkan pada Gambar 1 sebagai berikut: 


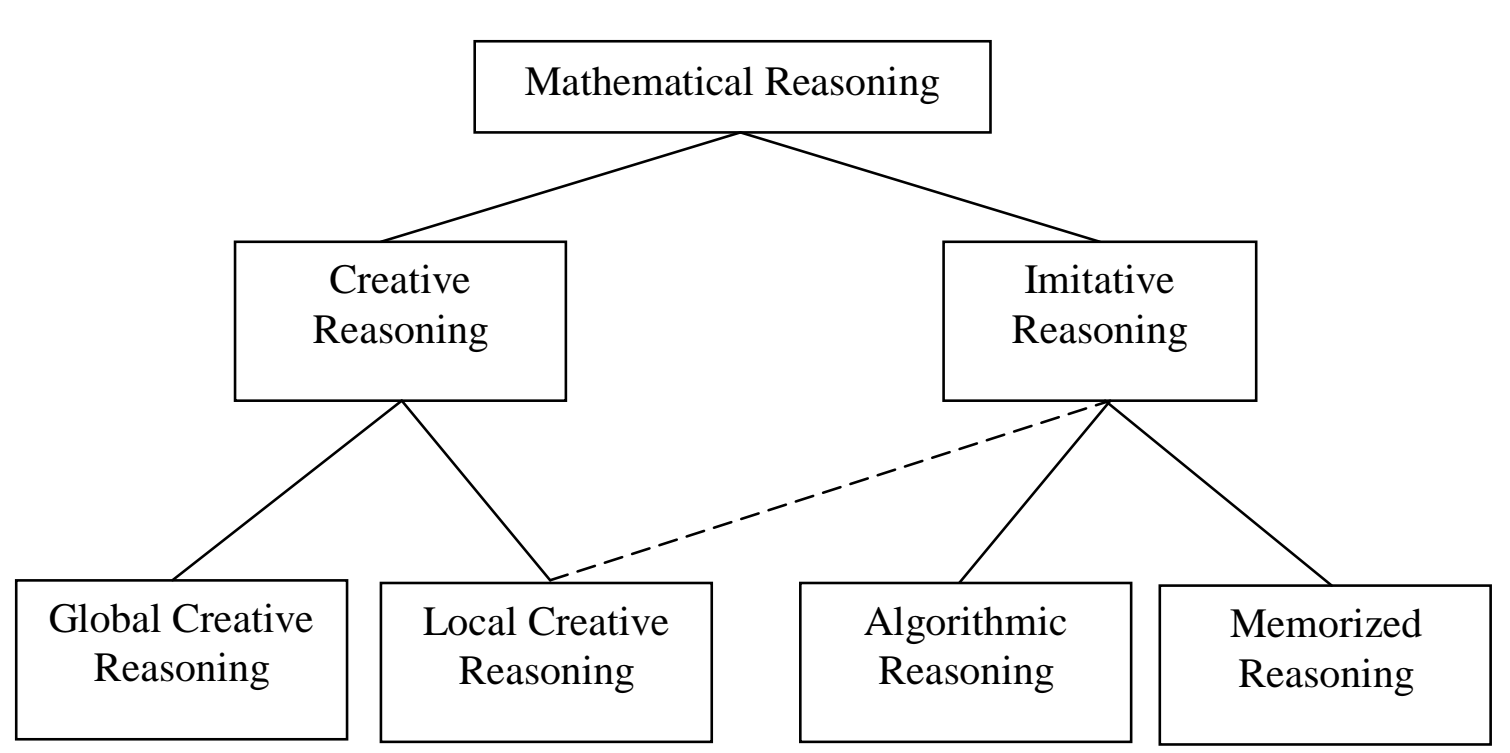

Gambar 1. Kerangka kerja penalaran matematika

Selain itu Lithner (2008) mengemukakan bahwa Penalaran Kreatif (Creative Reasoning / CR) yaitu suatu penalaran dengan mengutamakan proses pemecahan masalah yang meliputi kebaruan (novelty), masuk akal (plausible) dan berdasar matematis (mathematical foundation).

Berkaitan dengan sikap seseorang, Robbins (2010) mengemukakan bahwa sikap konsisten yang dimiliki seseorang dalam proses belajar-mengajar merupakan salah satu penentu keberhasilan sehingga dapat menyelaraskan sikap dan perilakunya sehingga tercapai tujuan yang diharapkan. Selain itu Syah (2010) juga mengemukakan terdapat beberapa faktor penentu keberhasilan belajar seseorang dalam pembelajaran matematika, yaitu faktor internal, eksternal dan pendekatan belajar. Salah satu bagian dari faktor internal siswa yakni Adversity Quotient (AQ).

Stoltz (2004) mengemukakan bahwa adversity merupakan kesulitan yang dihadapi oleh seseorang sehingga tidak sedikit orang patah semangat menghadapi tantangan tersebut. Sedangkan AQ merupakan suatu kegigihan seseorang dalam menghadapi segala rintangan dalam mencapai keberhasilan. Selain itu Stolz (2004) juga mengemukakan bahwa AQ memiliki empat dimensi pokok yang menjadi dasar penyusunan alat ukur AQ, yaitu: (1) Pengendalian (Control) merupakan respon seseorang terhadap kesulitan, baik lambat maupun spontanitas.; (2) Kepemilikan (Origin and Ownership) merupakan sejauh mana seseorang merasa dapat memperbaiki situasi.; (3) Jangkauan (Reach) merupakan sejauh mana kesulitan yang dihadapi dalam mempengaruhi kehidupannya.; dan (4) Daya tahan (Endurance) mencerminkan bagaimana seseorang mempersepsikan kesulitannya dan dapat bertahan melalui kesulitan tersebut. 
Berkaitan dengan tingkatan AQ yang dimiliki seseorang, terdapat tiga tipe atau tingkatan yaitu climber (tinggi), camper (sedang) dan quitter (rendah). Siswa yang memiliki tingkat climber tentu lebih mampu mengatasi kesulitan yang sedang dihadapi tetapi harus tetap diperhatikan dengan cara diberikan tugas tambahan pengayaan. Selain itu pada seseorang yang memiliki tingkat AQ climber juga dapat diberdayakan menjadi tutor sebaya kepada teman-temannya yang memiliki tingkat AQ camper dan quitter.

Berdasarkan hal tersebut, terlihat bahwa ketercapaian kemampuan penalaran kreatif matematis serta AQ tidak terlepas dari proses pembelajaran yang harus dilalui oleh seseorang. Agar pembelajaran lebih efektif, Muijs \& Reynol (2005) menyebutkan 6 (enam) elemen utama agar pembelajaran berlangsung efektif yaitu: (1) mempunyai sruktur yang jelas; (2) materinya dipersentasikan secara terstrutur dan jelas; (3) pembelajaran dirancang untuk memberikan keterampilan dasar dengan kecepatan langkah yang telah ditentukan; (4) mendemonstrasikan model pembelajaran secara jelas dan terstruktur; (5) menggunakan pemetaan konsep; dan (6) interaksi tanya jawab.

Keterlibatan siswa sebagai individu secara aktif dalam aktivitas proses belajarmengajar juga dapat menjadi faktor pendukung dalam pengembangan kemampuan penalaran kreatif matematis serta $\mathrm{AQ}$. Hal ini dikarenakan siswa dapat memiliki pengalaman terhadap pembelajaran matematika yang diajarkan, sehingga mereka dapat meningkatkan kemampuan penalaran kreatif matematis dan AQ yang menunjang terwujudnya tujuan pembelajaran matematika di kelas.

Hal tersebut didukung hasil penelitian Granström (2006) yang menunjukkan bahwa proses pembelajaran di kelas juga bergantung pada pendekatan pengajaran yang berbeda yang dapat mempengaruhi hasil belajar bagi seseorang. Demikian pula Oppendekker \& Van Damme (2006) menekankan bahwa pengajaran yang baik seyogyanya melibatkan hubungan komunikasi yang berinteraksi antara individu.

Berdasarkan studi pendahuluan yang telah dilakukan peneliti pada salah satu SMA di Kota Cimahi sebelumnya, diperlukan pembelajaran yang dapat membuat siswa lebih diberikan kesempatan untuk aktif baik secara fisik maupun mental. Hal ini terlihat pada saat beberapa siswa masih kesukaran dalam mengkonstruksi ide berdasarkan data yang didapatkan dari suatu permasalahan, sehingga pada akhirnya cenderung masih memiliki kesukaran dalam hal memunculkan ide atau gagasan yang selanjutnya dikomunikasikan kepada rekan lainnya. Hal tersebut juga didukung hasil penelitian Laswadi, Kusumah, Darwis \& Afgani (2016) yang menyarankan bahwa kecakapan matematis yang salah satu 
kemampuan yang diukur adalah kemampuan penalaran matematis dianggap perlu dikembangkan bagi siswa pada jenjang sekolah menengah atas.

Salah satu model pembelajaran yang diduga dapat mengoptimalkan pengembangan kemampuan penalaran kreatif matematis yaitu pembelajaran Argument Driven Inquiry yang merupakan model pengembangan Sampson, Walker, Dial \& Swanson (2010). Pembelajaran Argument Driven Inquiry lebih menekankan pada proses interaksi yang dilakukan oleh siswa dalam membangun pemahaman konsep yang dapat meningkatkan proses penalaran kreatif matematis siswa.

Penerapan pembelajaran Argument Driven Inquiry juga diduga dapat meningkatkan aktivitas bertanya dalam proses pembelajaran matematika yang nantinya dapat mengembangkan penalaran kreatif matematis siswa. Hal ini didasari oleh penelitian Hendriana, Rohaeti \& Hidayat (2017) bahwa ketercapaian penguasaan kemampuan bertanya matematis guru masih belum tercapai dengan baik pada indikator pengajuan permasalahan berupa pertanyaan non-rutin dan pertanyaan terbuka sehingga dapat berdampak pada kemampuan penalaran kreatif matematis siswa.

Berdasarkan permasalahan di atas, maka perlu dilakukan suatu penelitian yang difokuskan pada efektivitas peranan pembelajaran Argument Driven Inquiry dalam pencapaian kemampuan penalaran kreatif matematis ditinjau berdasarkan Adversity Quotient (AQ) siswa. Sehingga dapat dirumuskan permasalahan dan tujuan dalam penelitian ini adalah untuk mengetahui dan menelaah tentang: (1) apakah kemampuan penalaran kreatif matematis siswa yang memperoleh pembelajaran Argument Driven Inquiry (ADI) lebih baik daripada yang memperoleh pembelajaran langsung ditinjau berdasarkan keseluruhan dan tipe Adversity Quotient (Quitter/AQ Rendah, Camper/AQ Sedang, dan Climber/AQ Tinggi); (2) apakah terdapat efek interaksi antara pembelajaran dan tipe Adversity Qutient (AQ) dalam mengembangkan kemampuan penalaran kreatif matematis siswa; (3) Bagaimana ketercapaian dari kemampuan penalaran kreatif matematis siswa.

\section{METODE PENELITIAN}

Studi ini dirancang dalam bentuk eksperimen dengan disain kelompok kontrol dan postes saja yang bertujuan menelaah peranan pembelajaran Argument Driven Inquiry (ADI) terhadap kemampuan penalaran kreatif matematis siswa SMA berdasarkan Adversity Quotient (AQ). Populasi dalam penelitian ini adalah siswa SMA di Kota Cimahi, 
sedangkan sampel penelitian ini adalah 69 orang siswa SMA yang ditetapkan secara purposif kemudian ditetapkan secara acak yang termasuk ke dalam kelas eksperimen dan kelas kontrol. Tes kemampuan penalaran kreatif matematis pada penelitian ini disusun mengacu pada karakteristik kemampuan kreatif matematis serta pedoman penyususunan tes yang baik. Data akan dianalisis dengan menggunakan uji statistik Two-Way Annova untuk melihat perbedaan dan efek interaksi antara pembelajaran dan tipe Adversity Quotient (Quitter, Champer, dan Climber) dalam menghasilkan kemampuan penalaran kreatif matematis siswa.

\section{HASIL DAN PEMBAHASAN}

\section{Hasil}

Hasil temuan mengenai kemampuan penalaran kreatif matematis siswa disajikan pada Tabel 1 .

Tabel 1. Kemampuan Penalaran Kreatif Matematis

\begin{tabular}{ccccc}
\hline Tipe Adversity & \multicolumn{3}{c}{ Kemampuan Penalaran Kreatif Matematis } \\
\cline { 2 - 4 } Quotient & \multicolumn{3}{c}{ Kelas Pemb. ADI $(\mathrm{n}=34)$} & \multicolumn{2}{c}{ Kelas Pemb. Langsung (n = 35) } \\
\cline { 2 - 4 } & Rerata & SD & Rerata \\
\hline Climber & 7,969 & 0,598 & 6,563 & 1,488 \\
& $(79,69 \%)$ & & $(65,63 \%)$ & 1,346 \\
Champer & 7,125 & 1,353 & 6,346 & 1,228 \\
Quitter & $(71,25 \%)$ & & $(63,46 \%)$ & 1,262 \\
& 7,208 & 1,375 & $(6,424$ & \\
Keseluruhan & $(72,08 \%)$ & & $6,24 \%)$ & \\
& 7,261 & 1,297 & $(64,11 \%)$ & \\
\hline
\end{tabular}

Catatan: Skor ideal 10

Berdasarkan hasil deskripsi di atas, diperoleh interpretasi sebagai berikut:

1. Secara keseluruhan terdapat perbedaan kemampuan penalaran kreatif matematis siswa yang memperoleh pembelajaran Argument Driven Inquiry dengan yang pembelajaran langsung. Kemampuan penalaran kreatif matematis siswa pada kelas dengan pembelajaran Argument Driven Inquiry tergolong tinggi, sedangkan pada kelas dengan pembelajaran langsung kemampuan penalaran kreatif matematis tergolong sedang $(72,61 \%>64,11 \%)$.

2. Selain itu jika ditinjau berdasarkan tipe Adversity Quotient (AQ), kemampuan penalaran kreatif matematis siswa yang memperoleh pembelajaran Argument Driven Inquiry juga terlihat berbeda dan menunjukkan kemampuan penalaran kreatif matematis yang belajar dengan pembelajaran Argument Driven Inquiry lebih baik daripada yang belajar dengan pembelajaran langsung. Kemampuan penalaran kreatif 
matematis pada semua tipe Adversity Quotient (Climber, Champer, dan Quitter) pada pembelajaran Argument Driven Inquiry tergolong ke dalam kategori tinggi, sedangkan untuk semua tipe Adversity Quotient (Climber, Champer, dan Quitter ) tergolong ke dalam kategori sedang $(79,69 \%>65,63 \% ; 71,25 \%>63,46 \%$ dan $72,08 \%>64,24 \%)$.

3. Apabila ditinjau berdasarkan faktor mana yang mempengarui terhadap pengembangan kemampuan penalaran kreatif matematis, maka berdasarkan deskripsi pada Tabel 1 terlihat bahwa kedua faktor (baik pembelajaran maupun tipe AQ) masing-masing mempengaruhi terhadap pengembangan kemampuan penalaran kreatif matematis. Selain itu tidak terdapat efek interaksi antara pembelajaran dan tipe AQ secara bersama-sama dalam mengembangkan kemampuan penalaran kreatif matematis siswa.

Dalam hal mendukung deskripsi dari kemampuan penalaran kreatif matematis siswa yang telah dipaparkan di atas, maka perlu dilakukan analisis data mengenai kemampuan penalaran kreatif matematis siswa melalui uji statistik perbedaan rerata. Setelah dilakukan uji normalitas sebaran data kemampuan penalaran kreatif matematis siswa diperoleh bahwa data berdistribusi normal. Berdasarkan temuan tersebut, maka pengujian perbedaan rerata kemampuan di atas dilakukan dengan uji Two-Way Annova. (Tabel 2)

Tabel 2. Rangkuman Uji Two-Way Annova Pengembangan Kemampuan Penalaran Kreatif Matematis Siswa Berdasarkan Faktor Pembelajaran dan Tipe Adversity Quotient

\begin{tabular}{|c|c|c|c|c|c|}
\hline SUMBER & $\mathrm{JK}$ & $\mathrm{dk}$ & RJK & $\mathrm{F}^{h i t}$ & Sig \\
\hline Pendekatan Pembelajaran (A) & 5,876 & 1 & 5,876 & 4,827 & 0,032 \\
\hline Tipe AQ (B) & 28,736 & 2 & 14,368 & 11,802 & 0,000 \\
\hline $\mathrm{A} \times \mathrm{B}$ & 3,733 & 2 & 1,866 & 1,533 & 0,224 \\
\hline Inter & 76,696 & 63 & 1,217 & & \\
\hline
\end{tabular}

(Diambil dari output SPSS. 22)

1. Pendekatan Pembelajaran

$$
\begin{aligned}
& \mathrm{H}_{0}: \mu_{e}=\mu_{k} \\
& \mathrm{H}_{\mathrm{A}}: \mu_{e} \neq \mu_{k}
\end{aligned}
$$

Kriteria pengujian : Jika sig $>0,05$ maka $\mathrm{H}_{0}$ diterima

Berdasarkan Tabel 2 diperoleh nilai sig = 0,032; atau dengan kata lain sig < 0,05. Hal tersebut dapat disimpulkan bahwa terdapat perbedaan yang signifikan antara kemampuan penalaran kreatif matematis siswa yang pembelajarannya menggunakan pembelajaran Adversity Quotient dengan yang menggunakan pembelajaran langsung pada taraf signifikansi $5 \%$. 
2. Tipe Adversity Quotient (AQ)

$\mathrm{H}_{0}: \mu_{C l}=\mu_{C h}=\mu_{Q t}$

$\mathrm{H}_{\mathrm{A}}$ : Paling tidak terdapat satu tipe AQ yang berbeda secara signifikan dengan tipe AQ lainnya

Kriteria pengujian : Jika sig $>0,05$ maka $\mathrm{H}_{0}$ diterima

Berdasarkan Tabel 2 diperoleh nilai sig $=0,000$; atau dengan kata lain sig < 0,05; hal tersebut dapat disimpulkan bahwa paling tidak terdapat satu kelompok tipe AQ tertentu yang kemampuan penalaran kreatif matematisnya berbeda secara signifikan dengan tipe AQ lainnya pada taraf signifikansi 5\%. Untuk mengetahui tipe AQ mana yang berbeda secara signifikan dilakukan uji scheffe. Hasil perhitungannya disajikan pada Tabel 3.

Tabel 3. Uji Scheffe Pengembangan Kemampuan Penalaran Kreatif Matematis Berdasarkan Tipe Adversity Quotient

\begin{tabular}{lcccc}
\hline \multirow{2}{*}{ Tipe AQ $(\mathrm{I})$} & Tipe AQ $(\mathbf{J})$ & $\begin{array}{c}\text { Mean Difference } \\
(\mathrm{I}-\mathbf{J})\end{array}$ & Sig & Interpretasi \\
\hline Climber & Champer & 0,6696 & 0,324 & Tidak Berbeda \\
Champer & Quitter & $1,1438^{*}$ & 0,001 & Berbeda \\
Climber & Quitter & $1,8134^{*}$ & 0,000 & Berbeda \\
\hline
\end{tabular}

(Diambil dari output SPSS.22)

Berdasarkan Tabel 3 disimpulkan bahwa terdapat perbedaan yang signifikan antara kemampuan penalaran kreatif matematis pada tipe AQ Climber dengan Quitter dan Champer dengan Quitter dibandingkan dengan tipe AQ Climber dengan Champer pada taraf signifikansi 5\%. Implikasinya kemampuan penalaran kreatif matematis siswa untuk tipe AQ Quitter lebih berkembang daripada tipe AQ Climber dan Champer.

3. Efek Interaksi antara Pendekatan Pembelajaran dan Tipe AQ

$\mathrm{H}_{0}$ : Tidak terdapat efek interaksi antara pendekatan pembelajaran dengan Tipe AQ

$\mathrm{H}_{A}$ : Paling tidak terdapat satu selisih yang berbeda secara signifikan dari yang lainnya.

Berdasarkan Tabel 2 diperoleh nilai sig $=0,224$ lebih besar dari 0,05; hal tersebut dapat disimpulkan bahwa tidak terdapat efek interaksi yang signifikan antara pendekatan pembelajaran (ADI dan Langsung) dengan Tipe AQ (Climber, Champer, dan Quitter) dalam menghasilkan kemampuan penalaran kreatif matematis siswa pada taraf signifikansi $5 \%$.

\section{Pembahasan}

Berdasarkan hasil penelitian yang dilakukan terlihat bahwa siswa dapat melakukan proses bernalar yang cukup baik. Hal ini dapat dilihat dari proses penyelesaian yang 
dilakukan siswa memuat suatu pernyataan logis yang dapat dipertahankan kebenaran dari hasil pemikirannya tersebut. Pernyataan tersebut didukung oleh pendapat Ponte, Pereira \& Henriques (2012) yang mengemukakan bahwa penalaran matematis adalah proses menyimpulkan suatu penyelesaian masalah dari permasalahan yang diberikan. Selain itu sejalan juga dengan pendapat Velez \& Ponte (2013) yang menjelaskan bahwa penalaran matematis merupakan suatu pernyataan logis yang berasal dari proposisi yang diberikan, serta membuat dan menguji dugaan dari kasus-kasus tertentu sehingga menghasilkan kesimpulan secara umum.

Apabila ditelaah secara mendalam, hasil penelitian terhadap proses bernalar siswa tersebut merupakan hasil pemekiran yang heteregon. Hal ini terlihat bahwa siswa masih mengerjakan permasalahan dengan langkah-langkah/algoritma yang dihapal atau rutin dilakukan. Kegiatan tersebut merupakan kegiatan yang mencerminkan penguasaan siswa masih cenderung pada penalaran imitatif. Hal ini sejalan dengan pendapat Bergqvist (2007) juga mengemukakan bahwa penalaran imitatif (Imitatif Reasoning / IR) merupakan tipe penalaran yang dalam mencari solusi suatu permasalahan matematika dilakukan dengan cara meniru solusi seperti contoh soal maupun latihan yang terdapat pada buku teks seperti halnya mengingat algoritma atau langkah-langkah dari solusi suatu permasalahan. Selain itu Lithner (2008) berpendapat bahwa penalaran imitatif meliputi penalaran hapalan (Memorized Reasoning / MR), dan penalaran algoritma (Algorithmic Reasoning / AR).

Lithner (2008) juga mengemukakan bahwa penalaran hapalan dan penalaran algoritma terlihat tidak berbeda karena prosedur yang dilakukan siswa dalam melakukan strategi penyelesaian suatu masalah tetap harus dihapal. Namun tetap terdapat perbedaan antara penalaran hapalan dan penalaran algoritma, yakni pada penalaran algoritma walaupun siswa menghapal prosedur dalam melakukan strategi penyelesaian namun siswa tersebut tetap melakukan mencari solusinya sendiri lebih lanjut berdasarkan prosedur yang telah diingat sebelumnya. Sedangkan pada penalaran hapalan siswa hanya menyalin kembali jawaban yang telah diingatnya.

Walaupun sebagian besar siswa melakukan penyelesaian masalahnya dengan kemampuan penalaran imitatif, tetapi terdapat pula siswa yang memiliki kemampuan penalaran kreatif yaitu proses penyelesaian masalah yang dilakukan siswa dengan memperhatikan aspek kebaruan, masuk akan dan berdasar matematis. Hal ini sejalan dengan yang dikemukakan Lithner (2008) bahwa suatu penalaran dapat dikatakan sebagai 
penalaran kreatif matematis jika penalaran tersebut meliputi kebaruan (novelty), masuk akal (plausible) dan berdasar matematis (mathematical foundation).

Hasil penelitian terhadap kemampuan penalaran kreatif matematis siswa yang berkaitan berdasarkan pengelompokkan Adversity Quotient (AQ) memperlihatkan bahwa bagi siswa dengan AQ Quitter sering mengalami kesukaran dan mudah menyerah dalam menyelesaikan permasalahan yang diberikan, berbeda dengan siswa yang memiliki AQ Camper dan Climber. Hal ini sejalan dengan yang dikemukakan Phoolka (2012) yang mendefinisikan adversity quotient merupakan prediktor keberhasilan seseorang dalam menghadapi kesulitan, bagaimana ia berperilaku dalam situasi yang sulit, bagaimana ia mengontrol situasi, dia mampu menemukan asal-usul yang benar mengenai permasalahan, apakah ia mengambil kepemilikan dalam kondisi dan situasi tersebut, dan apakah dia mencoba untuk membatasi efek dari kesulitan serta bagaimana dia dapat optimis bahwa kesulitan itu akhirnya akan berakhir. Selain itu Parvathy \& Praseeda (2014) juga mengemukakan dengan mempertegas pernyataan "Students face a lot of situations or challenges in their daily life. To overcome or to face these problems, adversity quotient is required". Dengan kata lain siswa yang memiliki adversity quotient baik, maka ia akan mampu bertahan dalam menghadapi kesulitan dalam pembelajaran matematika.

Perlu disadari bahwa AQ merupakan motivasi yang kuat dari dalam diri siswa yang diharapkan dapat lebih menunjang keinginannya untuk berhasil dalam memecahkan permasalahan yang dihadapi. AQ juga sering dikatakan sebagai daya juang untuk menghadapi permasalahan. Dengan kata lain AQ merupakan kecerdasan yang dimiliki seseorang dalam mengatasi kesulitan untuk bertahan hidup.

Faktor pembelajaran Argument Driven Inquiry (ADI) terlihat memberikan pengaruh yang positif terhadap pencapaian kemampuan penalaran kreatif matematis karena diduga melalui langkah-langkah pembelajaran ADI mengutamakan empat aspek penting yang dapat mengembangkan kemampuan penalaran kreatif matematis, yakni: 1) mengkonstruksi dan menghasilkan kemampuan argumentasi dalam mendukung penjelasan matematis; 2) kemampuan menggunakan penjelasan matematis dalam pemecahan masalah; 3) berpartisipasi dalam proses diskusi; 4) menuliskan kesimpulan berdasarkan pendapatnya sendiri serta masukan dari pendapat orang lain. Hal ini sejalan dengan pendapat Alfieri (2011) yang mengemukakan bahwa pengaruh pembelajaran tanpa proses bimbingan sangat kecil (sedikit), sedangkan proses pembelajaran dengan proses bimbingan dapat 
meningkatkan keaktifan peserta didik dalam mengkonstruksi pengetahuannya menjadi optimal.

Berdasarkan temuan di lapangan, ketercapaian dari kemampuan penalaran kreatif matematis siswa belum sesuai dengan yang diharapkan. hasil ketercapaian tersebut terlampir pada Tabel 4.

Tabel 4. Ketercapaian Kemampuan Bertanya Matematis

\begin{tabular}{|c|c|c|c|}
\hline $\begin{array}{c}\text { Indikator } \\
\text { Penalaran Kreatif Matematis }\end{array}$ & Tipe AQ & $\begin{array}{l}\text { Kelas Pemb. } \\
\qquad A D I\end{array}$ & $\begin{array}{c}\text { Kelas Pemb. } \\
\text { Langsung }\end{array}$ \\
\hline \multirow{4}{*}{ Kebaruan (Novelty) } & Climber & $54 \%$ & $49 \%$ \\
\hline & Champer & $40 \%$ & $38 \%$ \\
\hline & Quitter & $39 \%$ & $40 \%$ \\
\hline & Keseluruhan & $46 \%$ & $43 \%$ \\
\hline \multirow{2}{*}{ Masuk akal (Plausible) } & Climber & $71 \%$ & $69 \%$ \\
\hline & Keseluruhan & $68 \%$ & $66 \%$ \\
\hline \multirow{4}{*}{ Berdasar Matematis (Mathematical Fondation) } & Climber & $72 \%$ & $72 \%$ \\
\hline & Champer & $69 \%$ & $66 \%$ \\
\hline & Quitter & $68 \%$ & $65 \%$ \\
\hline & Keseluruhan & $69 \%$ & $67 \%$ \\
\hline
\end{tabular}

Hasil temuan yang tertera pada Tabel 4 menyimpulkan bahwa ketercapaian penguasaan kemampuan penalaran kreatif matematis siswa masih belum tercapai dengan baik pada indikator kebaruan (novelty). Berdasarkan hasil observasi, kendala atau kesukaran yang dihadapi oleh siswa dalam melakukan penyelesaian permasalahan dengan melakukan jastifikasi asumsi melalui alasan yang didasarkan pada kebaruan (novelty) diantaranya yaitu:

1. Iklim budaya atau kebiasaan dari suasana pembelajaran di kelas dalam mengaplikasikan kegiatan pembelajaran yang jarang atau sama sekali tidak pernah untuk mengarahkan siswa melakukan proses berpikir kreatif yang dapat menghasilkan kemampuan penalaran kreatif dengan indikator kebaruan (novelty). Hal ini mengakibatkan kondisi awal siswa hanya terbiasa dalam menerima materi tanpa memikirkan konteks dari materi secara lebih mendalam dan komprehensif.

2. Tuntutan kurikulum yang dengan tidak sengaja dapat menghasilkan output belajar siswa yang lebih mementingkan kuantitas berupa hasil kelulusan daripada mutu berupa proses pembelajaran yang bermakna.

Dengan adanya kendala yang dialami oleh siswa tersebut, seyogyanya diperlukan suatu usaha berupa pembelajaran yang inovatif dengan tujuan mengembangkan kemampuan matematis siswa yang salah satunya adalah penalaran kreatif agar lebih baik lagi. Kendala tersebut sejalan dengan yang dikemukakan Hendriana (2012) bahwa munculnya kesulitan kesulitan siswa dalam membuat model matematika untuk 
memecahkan persoalan matematika dikarenakan pembelajaran yang diajarkan masih monoton (tidak berpusat kepada siswa).

\section{KESIMPULAN}

Berdasarkan hasil dan pembahasan, maka dapat disimpulkan bahwa:

1. Kemampuan penalaran kreatif matematis siswa yang memperoleh pembelajaran Argument Driven Inquiry (ADI) lebih baik daripada yang memperoleh pembelajaran langsung ditinjau berdasarkan keseluruhan dan tipe Adversity Quotient (Quitter/AQ Rendah, Champer/AQ Sedang, dan Climber/AQ Tinggi). Secara keseluruhan kemampuan penalaran kreatif matematis baik yang memperoleh pembelajaran Argument Driven Inquiry (ADI) maupun yang memperoleh pembelajaran langsung tergolong ke dalam kategori cukup. Namun jika ditinjau berdasarkan tipe Adversity Quotient (AQ), yang memperoleh pembelajaran dengan Argument Driven Inquiry dengan tipe Climber tergolong ke dalam kategori tinggi dan yang tipe Champer serta Quitter tergolong cukup, sedangkan yang memperoleh pembelajaran langsung pada Adversity Quotient tipe Climber dan Champer tergolong kategori cukup dan tipe Quitter tergolong kategori rendah.

2. Faktor pembelajaran dan tipe Adversity Quotient (AQ) masing-masing mempengaruhi ketercapaian kemampuan penalaran kreatif matematis siswa. Selain itu, terdapat efek interaksi antara pembelajaran dan AQ secara bersama-sama dalam mengembangkan kemampuan penalaran kreatif matematis siswa.

3. Ketercapaian penguasaan kemampuan penalaran kreatif matematis siswa masih belum tercapai dengan baik pada indikator kebaruan (novelty).

\section{REKOMENDASI}

Berdasarkan kesimpulan dari penelitian ini, maka penulis merekomendasikan bahwa urgensi permasalahan yang dapat disolusikan dengan adanya suatu usaha berupa pembelajaran inovatif seperti pembelajaran Argument Driven Inquiry (ADI) yang diaplikasikan mulai dari pendidikan calon guru sehingga dapat mengimplementasikan kemampuan penalaran kreatif matematis guru kepada siswa yang nantinya baik guru maupun siswa akan terbiasa untuk berpikir secara komprehensif pada proses pemecahan masalah dalam bidang pendidikan matematika. 
Berdasarkan hasil temuan tentang terdapatnya efek interaksi antara pembelajaran dan AQ secara bersama-sama dalam mengembangkan kemampuan penalaran kreatif matematis siswa, diharapkan dapat dijadikan pertimbangan bagi peneliti yang memiliki fokus penelitian tentang kemampuan penalaran kreatif untuk mengintegrasikan Adversity Quotient (AQ) dengan pendekatan pembelajaran yang akan dijadikan variabel bebas dalam penelitiannya.

\section{REFERENSI}

Alfieri, L. (2011). Does Discovery-Based Instruction Enhance Learning?. Journal of Educational Psychology American Psychological Association, 103(1), 1-18.

Bergqvist, E. (2007). Types of reasoning required in university exams in mathematics. The Journal of Mathematical Behavior, 26(4), 348-370. doi:10.1016/j.jmathb.2007.11.001

Depdiknas. (2006). Kurikulum Tingkat Satuan Pendidikan Standar Kompetensi SMP dan MTs. Jakarta: Depdiknas.

Granström, K. (2006). Group phenomena and classroom management. A Swedish perspective. In C. M. Evertson \& C. S. Weinstein (Eds.), Handbook for Classroom Management: Research, Practice, and Contemporary Issues (pp. 1141-1160). New York: Erlbaum.

Hendriana, H. (2012). Pembelajaran Matematika Humanis dengan Metaphorical Thinking untuk Meningkatkan Kepercayaan Diri Siswa. Infinity, 1(1), 90-103.

Hendriana, H., Rohaeti, E.E., \& Hidayat, W. (2017). Metaphorical Thinking Learning and Junior High School Teachers' Mathematical Questioning Ability. Journal on Mathematics Education, 8(1), 55-64.

Killpatrick, J., Swafford, J., \& Findell, B. (2001). Adding it up: Helping Children Learn Mathematics. Washington, DC: National Academy Press.

Laswadi, Kusumah, Y.S., Darwis, S., Afgani, J.D. (2016). Developing conceptual understanding and procedural fluency for junior high school students through modelfacilitated learning (MFL). European Journal of Science and Mathematics Education, 4(1), 67-74.

Lithner, J. (2008). A Research Framework for Creative and Imitative Reasoning. Educational Studies in Mathematics, 67(3), 255-276.

Muijs D \& Reynolds D (2005) 'Effective Teaching-Introduction \& Conclusion' 2nd edition. London: Sage Publications.

Oppendekker, M.C. \& Van Damme, J. (2006). Teacher Characteristics and teaching styles as effectiveness enhancing factors of classroom practice. Teaching and Teacher Education, 22, 1-21. doi:10.1016/j.tate.2005.07.008

Parvathy, U. \& Praseeda, M. (2014). Relation between Adversity Quotient and Academic Problem among Student Teachers. Journal of Humanities and Social Sicence, 19(11), 23-26.

Phoolka, S. K. (2012).Adversity Quotient: A New Paradigm in Management to Explore. Research Journal of Social Science and Management, 2(7).

Ponte, J. P., Pereira, M.J., \& Henriques, A. (2012). O raciocínio matemático nos alunos do ensino básico e do ensino superior. Praxis Educativa, 7(2), 355-377.

Robbins, S. P. (2010). Manajemen. Jakarta: Erlangga 
Sampson V, Walker J, Dial K, \& Swanson J. (2010). "Learning to write in undergraduate chemistry: The impact of Argument-Driven Inquiry." Paper presented at the 2010 Annual International Conference of the National Association of Research in Science Teaching (NARST). Philadelphia, PA.

Shadiq, F., (2007). Laporan Hasil Seminar dan Lokakarya Pembelajaran Matematika 15 16 Maret 2007 di P4TK (PPPG) Matematika. Yogyakarta.

Stoltz, P. G. (2004). Adversity Quotient: Mengubah Hambatan Menjadi Peluang. Edisi Kelima. Jakarta: Grasindo.

Syah, M. (2010). Psikologi Belajar. Jakarta: Rajagrafindo Persada.

Velez, I. dan Ponte, J.P.D.A (2013).Representations and reasoning strategies of Grade 3 students in problem solving.Dalam B. Ubuz., C. Haser., M.A. Marioti (Eds). Proceedings of the Eight Congress of the European Society for Research in Mathematics Education (pp. 383-391). Ankara: Middle East Technical University. 